\title{
Metabotropic Glutamate Receptors Drive the Endocannabinoid System in Hippocampus
}

\author{
Namita Varma, ${ }^{1}$ Gregory C. Carlson, ${ }^{1}$ Catherine Ledent, ${ }^{2}$ and Bradley E. Alger ${ }^{1}$ \\ ${ }^{1}$ Department of Physiology and Program in Neuroscience, University of Maryland School of Medicine, Baltimore, \\ Maryland 21201, and 2/nstitut de Recherche Interdisciplinaire en Biologie Humaine et Nucléaire, Université libre de \\ Bruxelles, B-1070 Brussels, Belgium
}

\begin{abstract}
Endocannabinoids are key intercellular signaling molecules in the brain, but the physiological regulation of the endocannabinoid system is not understood. We used the retrograde signal process called depolarization-induced suppression of inhibition (DSI) to study the regulation of this system. DSI is produced when an endocannabinoid released from pyramidal cells suppresses IPSCs by activating CB1R cannabinoid receptors located on inhibitory interneurons. We now report that activation of group I metabotropic glutamate receptors (mGluRs) enhances DSI and that this effect is blocked by antagonists of
\end{abstract}

Cannabinoids are the active ingredients in marijuana and hashish (Ameri, 1999). Endogenous cannabinoids are synthesized from membrane lipids (Di Marzo et al., 1998) through $\mathrm{Ca}^{2+}$. dependent processes and diffuse through the membrane where they activate the same receptors as do exogenous cannabinoids. The main cannabinoid receptor in the brain, CB1R, is coupled to G-proteins (Matsuda et al., 1990). CB1R is often precisely localized to presynaptic nerve terminals (Katona et al., 1999; Tsou et al., 1999), and when activated by exogenously applied ligands, reduces glutamate (Levenes et al., 1998; Takahashi and Linden, 2000) or GABA (Katona et al., 1999; Hoffman and Lupica, 2000) output. Suppression of evoked IPSCs (eIPSCs) by exogenous cannabinoids is absent in CB1 ${ }^{-/-}$mice (Hajos et al., 2000). Endogenous cannabinoids also reduce GABA (Ohno-Shosaku et al., 2001; Wilson and Nicoll, 2001) and glutamate (Kreitzer and Regehr, 2001) release. The increasing evidence for the role of endocannabinoids in normal behavior (Calignano et al., 1998, 2000; Di Marzo et al., 2001) together with the need to understand the effects of the psychoactive cannabinoid drugs on the brain, underscores the importance of understanding the regulation of the endocannabinoid system.

Depolarization-induced suppression of inhibition (DSI) is a retrograde signal process that occurs between principal cells and specific GABAergic interneurons in hippocampus (Pitler and Alger, 1992; Alger et al., 1996), cerebellum (Llano et al., 1991), and neocortex (Zilberter, 2000). DSI is induced by an increase in

\footnotetext{
Received Aug. 28, 2001; revised Sept. 24, 2001; accepted Sept. 25, 2001.

This work was supported by Grants NS36612 and NS30219 from the National Institutes of Health. We thank M. Ennis, A. Keller, S. Thompson, and D. Weinreich for their critical reading of this manuscript. We thank J. Jones for assistance with the mouse PCR, and E. Elizabeth for expert typing and editorial assistance.

N.V. and G.C. contributed equally to this work.

Correspondence should be addressed to Dr. B. E. Alger, Department of Physiology, University of Maryland School of Medicine, 655 West Baltimore Street, Baltimore, MD 21201. E-mail: balger@umaryland.edu.

Copyright (ㄷ) 2001 Society for Neuroscience 0270-6474/01/210001-05\$15.00/0
}

both mGluRs and of CB1R. We also found that DSI is absent in CB1R knock-out $\left(\mathrm{CB} 1 \mathrm{R}^{-1-}\right)$ mice, and, strikingly, that mGluR agonists have no effect on IPSCs in these mice. We conclude that group I mGluR-induced enhancement of DSI, and suppression of IPSCs, is actually mediated by endocannabinoids. This surprising result opens up new approaches to the investigation of cannabinoid actions in the brain.

Key words: DSI; IPSCs; retrograde; transmitter release; cannabinoid; CB1; mGluR; CA1; presynaptic; disinhibition

$\mathrm{Ca}^{2+}$ in the postsynaptic cell (Llano et al., 1991; Pitler and Alger, 1992; Lenz and Alger, 1999), but expressed as a decrease in GABA release from the interneurons (Vincent et al., 1992; Alger et al., 1996; Morishita and Alger, 1997). Recent evidence suggests that an endocannabinoid is the retrograde messenger in DSI (Ohno-Shosaku et al., 2001; Wilson et al., 2001; Wilson and Nicoll, 2001). Yet, previous observations implied a role for metabotropic glutamate receptors (mGluRs) in DSI (Glitsch et al., 1996; Morishita et al., 1998), because group I mGluR agonists can occlude DSI and mimic all its features (Glitsch et al., 1996; Morishita et al., 1998; Morishita and Alger, 1999). The relationships between the metabotropic glutamate and endocannabinoid systems remained unresolved. A unifying hypothesis would be that the glutamate and endocannabinoid systems can cooperate in the process of DSI induction.

To investigate the relationship between the mGluR and CB1R systems, we studied IPSCs in the CA1 region of the hippocampal slice. Using pharmacological tools in rats, as well as CB1 $\mathrm{R}^{-1-}$ mice (Ledent et al., 1999), we show that group I mGluR agonists enhance DSI and suppress IPSCs through CB1R activation. Both mGluR effects are blocked by CB1R antagonists, and most importantly, mGluR agonists do not suppress IPSCs in CB1 $\mathrm{R}^{-1-}$ mice. Neither presynaptic inhibition of GABA release by other

This article is published in The Journal of Neuroscience, Rapid Communications Section, which publishes brief, peerreviewed papers online, not in print. Rapid Communications are posted online approximately one month earlier than they would appear if printed. They are listed in the Table of Contents of the next open issue of JNeurosci. Cite this article as: JNeurosci, 2001, 21:RC188 (1-5). The publication date is the date of posting online at www.jneurosci.org.

http://www.jneurosci.org/cgi/content/full/5899 
G-protein-coupled receptors (GPCRs) nor other mGluRmediated responses are altered in the mutant mice. By revealing that some effects that have been attributed directly to mGluR activation are mediated by activation of CB1R, the results have profound implications for understanding both endocannabinoid and metabotropic glutamate systems in brain. While this paper was in the process of submission, it was reported by Maejima et al. (2001) that mGluR activation in cerebellum releases endocannabinoids and thereby indirectly suppresses EPSCs by activation of cannabinoid receptors. Our results are in agreement with theirs and argue that mediation of group I mGluR effects by endocannabinoids may be a widespread phenomenon in the brain.

\section{MATERIALS AND METHODS}

Whole-cell recordings were made from presumed CA1 pyramidal cells in hippocampal slices from 20- to 40-d-old rats (Figs. 1, 2) or mice (Fig. 3). Pyramidal cells were held under whole-cell voltage clamp at $-70 \mathrm{mV}$, and DSI was induced by a voltage step to $0 \mathrm{mV}$ for between 1 and $3 \mathrm{sec}$ to produce a maximal level of DSI (Lenz and Alger, 1999). All cells with low $(\leq 300 \mathrm{pA})$, stable holding current at $-70 \mathrm{mV}$ and robust voltagegated $\mathrm{Ca}^{2+}$ currents showed DSI, provided the appropriate target IPSCs were present (Martin et al., 2001; Wilson and Nicoll, 2001). In all experiments $50 \mu \mathrm{M}$ APV and $20 \mu \mathrm{M}$ 1,2,3,4-tetrahydro-6-nitro-2,3dioxobenzo[f]quinoxaline-7-sulfonamide (NBQX) were present to block ionotropic glutamate receptors. Slices, $400-\mu \mathrm{m}$-thick, were cut from both hippocampi. After incubation for $>1 \mathrm{hr}$ at room temperature, slices were submerged in a constant perfusion chamber, and conventional recordings were made (Alger et al., 1996), also at room temperature. The extracellular saline contained (in mM): $120 \mathrm{NaCl}, 3 \mathrm{KCl}, 2 \mathrm{MgSO}_{4}, 1 \mathrm{NaH}_{2} \mathrm{PO}_{4}$, $25 \mathrm{NaHCO}_{3}, 10$ glucose, and $2.5 \mathrm{CaCl}_{2}$ and was bubbled with $95 \% \mathrm{O}_{2}$ and $5 \% \mathrm{CO}_{2}$. The recording pipette filling solution contained (in $\mathrm{mm}$ ): $100 \mathrm{CsCH}_{3} \mathrm{SO}_{3}, 50 \mathrm{CsCl}, 10 \mathrm{HEPES}, 0.2$ BAPTA, $2 \mathrm{Mg}$-ATP, $1 \mathrm{KCl}, 1$ $\mathrm{MgCl}_{2}$, and $5 \mathrm{QX}-314$. Electrode resistance in the bath measured 2-5 $\mathrm{M} \Omega$. Electrode resistance in the cell could be compensated by $\sim 70 \%$, and recordings were stopped when it increased to $>20 \mathrm{M} \Omega$. IPSCs were elicited with bipolar extracellular stimulating electrodes (David Kopf Instruments, Tujunga, CA). Stimulus pulses were $100 \mu \mathrm{sec}$ in duration and from $50-400 \mu \mathrm{A}$ in amplitude. $\mathrm{CB} 1 \mathrm{R}^{-/-}$and $\mathrm{CB} 1 \mathrm{R}^{+/+}$mice were identified by PCR. Statistical comparisons were made with one-way ANOVA followed by a test for multiple comparisons. Otherwise, paired or unpaired $t$ tests were used $(p<0.05)$, as appropriate.

\section{RESULTS}

\section{mGluR antagonists block DSI, and agonists enhance it}

The broad-spectrum mGluR antagonist $(S)$ - $\alpha$-methyl-4carboxyphenylglycine (MCPG) reduces DSI when applied at 2-5 mM (Morishita et al., 1998; Morishita and Alger, 1999), which is consistent with the involvement of the mGluR5 receptor [which predominates on CA1 pyramidal cells (Littman and Robinson, 1994)] in DSI. Nevertheless, the high concentrations might produce nonspecific effects. Therefore, we tested the mGluR antagonist LY341495, at concentrations that block all known mGluRs (Fitzjohn et al., 1998). After establishing that DSI was present in a given cell, we applied LY341495 and found that it significantly, although variably, reduced DSI (Fig. 1a). Thus, the effects of LY341495 and MCPG establish a link between mGluRs and DSI.

Another link is provided by the observation that glutamate uptake blockers enhance DSI in the presence of NBQX and APV (Morishita and Alger, 1999), presumably by increasing extracellular glutamate levels and activating mGluRs. We tested this inference by bath applying a low concentration of the groups I and II mGluR agonist, $1 S, 3 R$-ACPD (ACPD). We maximized detectability of increases in DSI by using a fixed voltage step in the range of $100-1000 \mathrm{msec}$ in duration (Lenz
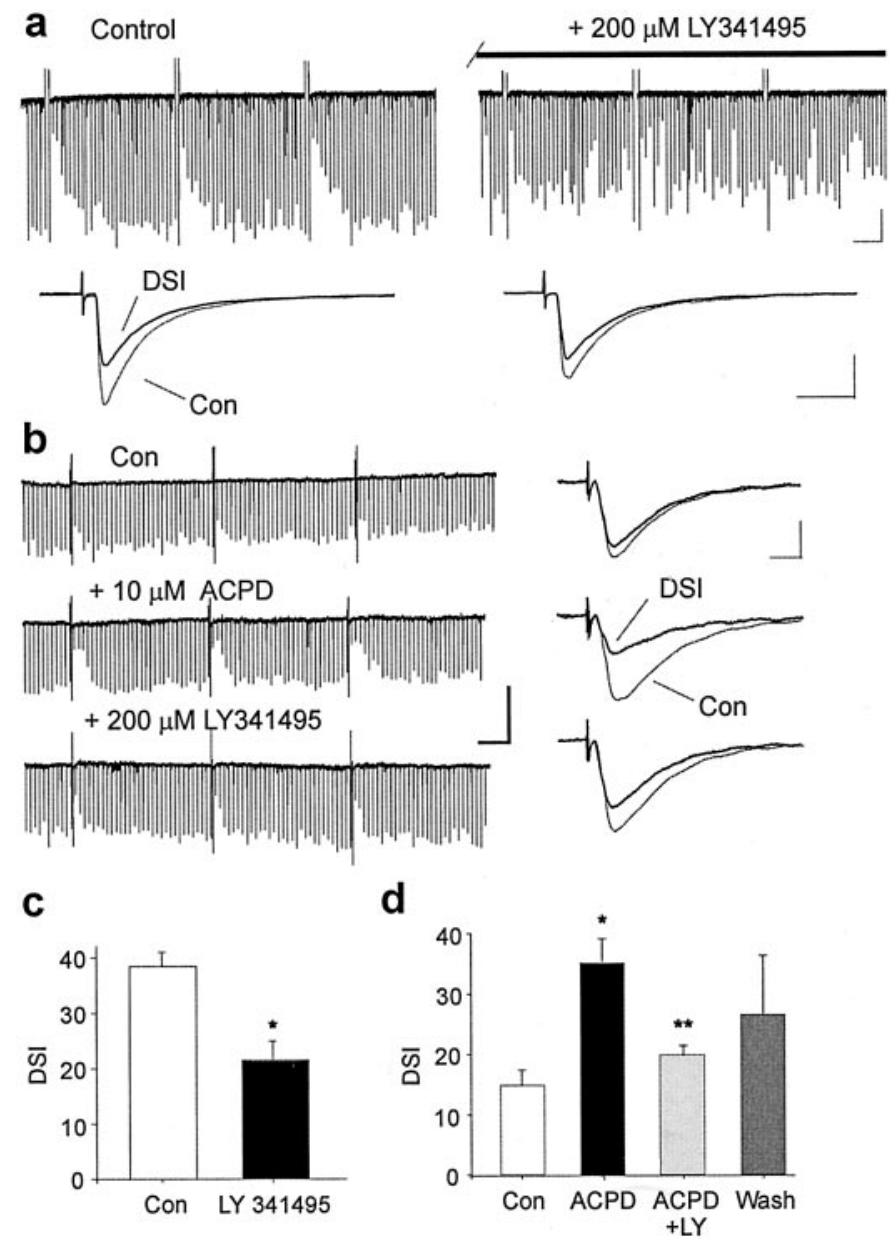

Figure 1. The mGluR antagonist LY341495 decreases DSI and suppresses ACPD-induced enhancement of DSI. $a$, Sample traces show DSI in control and after 7 min of bath application of $200 \mu \mathrm{M}$ LY341495. Below are means of eight eIPSCs before (thin line) and five eIPSCs after (thick line) the DSI step. Histogram shows LY341495 significantly decreases DSI (control, $38.4 \pm 2.5 \%$; LY341495, $21.2 \pm 3.8 \% ; n=4 ; p<0.05$ ). In all experiments DSI was measured as the mean reduction of the eIPSC expressed as a percentage of the control eIPSC for three trials; $n$ values indicate numbers of cells. Except in Figure 1, three eIPSCs before and three eIPSCs after the voltage step were used to calculate DSI. $b$, Sample traces showing minimal DSI in control, after DSI enhancement by ACPD, and after suppression of enhanced DSI by LY341495. Averaged traces in each condition are shown at right. Group data showing significant enhancement of DSI by ACPD and reversible reduction of enhanced DSI by LY341495 [control DSI, $14.9 \pm 2.5 \% ; n=15$; DSI in low $(10$ or $20 \mu \mathrm{M})$ ACPD, $31.2 \pm 3.7 \% ; n=15 ; p<0.001$; DSI in low ACPD plus 100 or 200 $\mu \mathrm{M}$ LY341495, $19.8 \pm 1.7 \% ; n=3 ; p<0.05$; DSI after washing LY341495, $26.6 \pm 9.8 \% ; n=3$ ]. Calibration: $a, b$, (continuous traces) 500 pA, $20 \mathrm{sec} ; a$ (mean traces), $400 \mathrm{pA}, 40 \mathrm{msec} ; b$, (mean traces) $300 \mathrm{pA}, 30$ msec. In all figures single asterisks denote significant differences from control values, and double asterisks denote significant differences compared with values obtained in the previous treatment.

and Alger, 1999) to induce a minimal level of DSI in control saline. When a low concentration of ACPD was added to the perfusate, markedly greater DSI was induced (Fig. 1b); the mean enhancement over control levels was $304 \pm 57.3 \%(n=$ 15), whereas the baseline eIPSC was suppressed by only $9.2 \pm$ 4.9\%. Enhancement of DSI was reversed by LY341495 applied in the continued presence of ACPD, showing that activation of mGluRs is responsible (Fig. 1b). 


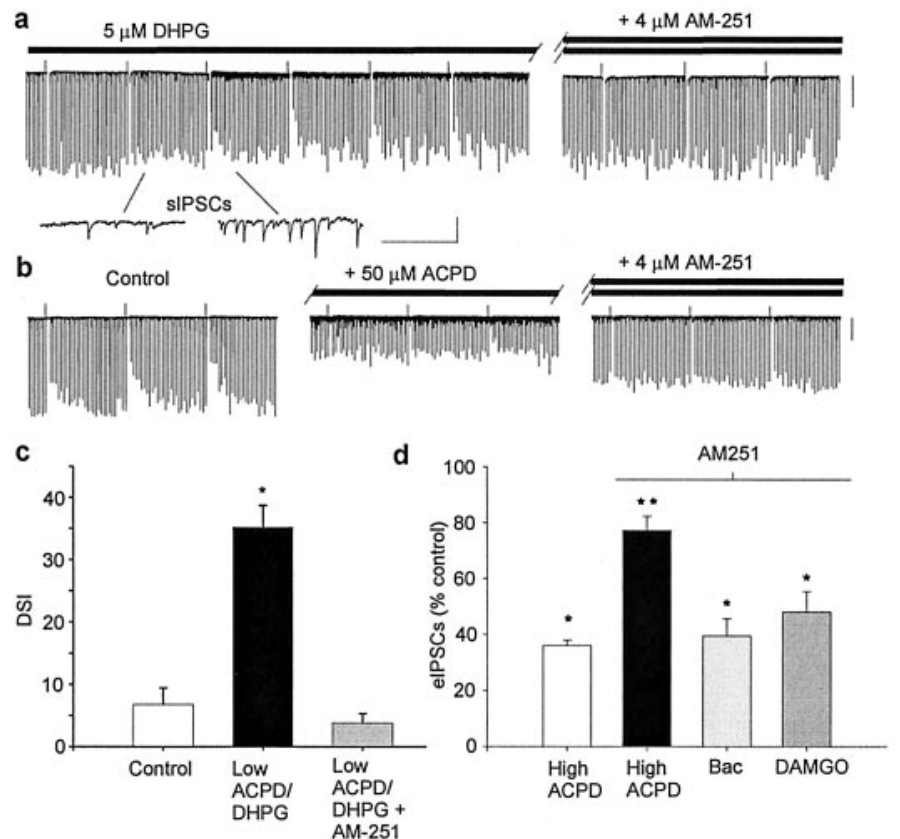

Figure 2. The CB1R antagonist AM-251 blocks group I mGluRmediated enhancement of DSI and suppression of eIPSCs. $a$, Bath application of the group I mGluR agonist DHPG was begun $2 \mathrm{~min}$ before the start of the trace, and 1-sec-long voltage steps to $0 \mathrm{mV}$ were given at the upward vertical lines. DHPG slightly reduced the eIPSCs, increased sI PSC activity, and enhanced DSI. AM-251 applied in the continued presence of DHPG for $20 \mathrm{~min}$ to the same cell virtually abolished DSI without affecting eIPSCs. $b$, DSI was induced by 500 -msec-long voltage steps in control conditions. Application of a high concentration $(50 \mu \mathrm{M})$ of ACPD reduced eIPSCs and occluded DSI, as reported by Morishita et al. (1998). Application of AM-251 together with ACPD restored eIPSC amplitudes to near control values, but did not restore DSI. Calibration: $a, b$ (continuous traces), $100 \mathrm{pA}, 90 \mathrm{sec} ; a$, inset, $10 \mathrm{pA}, 1$ sec. $c$, Group data from cells $(n=7)$ in which a brief voltage pulse was given first in control conditions, then in $10 \mu \mathrm{M}$ ACPD, and then in the presence of ACPD together with $4 \mu \mathrm{M}$ AM-251. DSI in $10 \mu \mathrm{M}$ ACPD $(35.2 \pm 3.5 \%)$ was significantly greater $(p<0.001)$ than DSI in control $(6.8 \pm 2.6 \%)$, and DSI in low ACPD plus AM-251 $(3.8 \pm 1.6 \%)$ was significantly less $(p<0.001)$ than DSI in low ACPD alone. $d$, Group data $(n=4$; left two bars; $p<0.001)$ showing that AM-251 reversed the high ACPD-mediated suppression of eIPSCs (eIPSC suppression in high ACPD, $36.1 \pm 2.0 \%$ of control; eIPSC suppression in high ACPD plus AM-251, 77.3 + 4.9\% of control). Baclofen and DAMGO continued to cause significant $(p<0.002)$ suppression of eIPSCs in the presence of AM-251 (suppression by baclofen, $39.5 \pm 6.2 \%$ of control; $n=4$; suppression by DAMGO, $48.1 \pm 7.2 \%$ of control; $n=5$ ).

\section{CB1R antagonists block mGluR-mediated enhancement of DSI and IPSC suppression}

We considered that mGluR activation might suppress IPSCs independently of the endocannabinoid system and enhance DSI through an additive effect. Therefore, we asked whether the CB1R antagonist AM-251 would block the capability of group I mGluR agonists to enhance DSI. After establishing a stable baseline level of minimal DSI, and then enhancing it by application of low concentrations of ACPD $(n=4)$ or $(R S)-3,5-$ dihydroxyphenylglycine (DHPG) $(n=3)$, we applied $4 \mu \mathrm{M}$ AM251 in the continued presence of the agonist. As shown in Figure $2 a$, the enhancement of DSI was also abolished by AM-251. Note that mGluR agonists also transiently increased spontaneous IPSC (sIPSC) frequency (Fig. 2a, inset). If AM-251 was applied first, the mGluR agonist still produced a robust increase in sIPSC frequency, but depressed eIPSCs only slightly $(n=4$; data not shown). The effects of ACPD and DHPG were not significantly different, and therefore the results have been pooled in Figure $2 c$. The CB1R antagonist SR141716A $(n=2)$ also blocked DSI enhancement (data not shown). These data argue that mGluR agonists enhance DSI indirectly via CB1R activation.

It is thought that group I mGluR activation suppresses IPSCs (Gereau and Conn, 1995; Morishita et al., 1998) by activating presynaptic inhibitory receptors on GABAergic nerve terminals; yet the previous experiment showed that mGluRs can act in concert with an endocannabinoid in suppressing IPSCs during DSI. We wondered whether the inhibition of GABA release caused by group I mGluR agonists might be mediated by CB1R activation. We found that after maximal IPSC suppression was produced by $50 \mu \mathrm{M}$ ACPD, the addition of AM-251 in the continuous presence of ACPD restored the IPSCs to near control levels (Fig. 2b). This suggests that the suppression of IPSCs by mGluR agonists is mediated by CB1R activation. The prevention of IPSC suppression did not represent a general capability of AM-251 to prevent inhibition of GABA release, because it did not prevent the $\mathrm{GABA}_{\mathrm{B}}$ receptor agonist baclofen or the $\mu$-opioid receptor agonist Tyr-DAla-Gly-NMe-Phe-Gly-ol (DAMGO) from suppressing IPSCs (Fig. 2c). Thus, the effects of AM-251 are selective for mGluRmediated IPSC suppression.

\section{mGluR agonists do not suppress IPSCs in CB1R $^{-1-}$ mice}

The preceding results suggest that the mGluR and CB1R systems may be functionally interrelated. However, this conclusion depends heavily on the actions of CB1R antagonists, which are in fact inverse agonists at CB1R. Although they bind specifically to cannabinoid receptors (CBRs), the inverse agonists stabilize the $\mathrm{CBR}$ in a G-protein-bound state and can thereby inhibit the actions of agonists at other GPCRs that share a common pool of G-proteins with CBRs (Bouaboula et al., 1997; Vasquez and Lewis, 1999). This inhibition of the activation of other GPCRs resulting from G-protein sequestration on CB1R has been called "cross-over". The possibility of cross-over could explain our results, because both mGluR and CB1R are pertussis toxinsensitive GPCRs (Pin and Duvoisin, 1995; Pertwee, 1997).

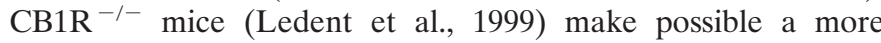
stringent test of the postulated relationship between mGluR and CB1R.

First we confirmed that the endocannabinoid system is deficient in these mice in our hands. We found that DSI occurs in $\mathrm{CB} 1 \mathrm{R}^{+/+}$mice $(35.4 \pm 5.2 \%$ IPSC reduction; $n=5)$, but not in $\mathrm{CB} 1 \mathrm{R}^{-/-}$mice $(3.5 \pm 1.0 \%$ IPSC reduction; $n=7$; significant difference, $p<0.001$ ), as reported (Wilson et al., 2001). Peak voltage-dependent $\mathrm{Ca}^{2+}$ current tail currents in $\mathrm{CB} 1 \mathrm{R}^{-1-}$ mice $(1.31 \pm 0.16 \mathrm{nA} ; n=7)$ did not differ from those of $\mathrm{CB} 1 \mathrm{R}^{+/+}$ mice $(1.23 \pm 0.12 \mathrm{nA} ; n=5)$, arguing that the absence of DSI in the $\mathrm{CB} 1 \mathrm{R}^{-/-}$animals was not attributable to a deficit in the $\mathrm{Ca}^{2+}$ influx required for DSI induction (Llano et al., 1991; Lenz and Alger, 1999). The synthetic CB1R agonist WIN 55212-2 (2 $\mu \mathrm{M}$ ) had typical (Hoffman and Lupica, 2000) suppressive effects on eIPSCs from CB1R ${ }^{+/+}$mice (IPSC suppression $63.1 \pm$ $10.7 \% ; n=3)$, but had no effect on eIPSCs in CB1R ${ }^{-1-}$ mice (IPSC reduction $6.4 \pm 5.5 \% ; n=3$; significant difference, $p<$ $0.05)$, as reported by Hajos et al. (2000). eIPSCs in CB1R ${ }^{-/-}$ mice were suppressed by DAMGO $(47.8 \pm 5.5 \% ; n=5 ; p<$ $0.001)$ and by baclofen $(47.0 \pm 8.8 \% ; n=5 ; p<0.05)$, showing that GPCR-mediated responses were not generally defective in 
a
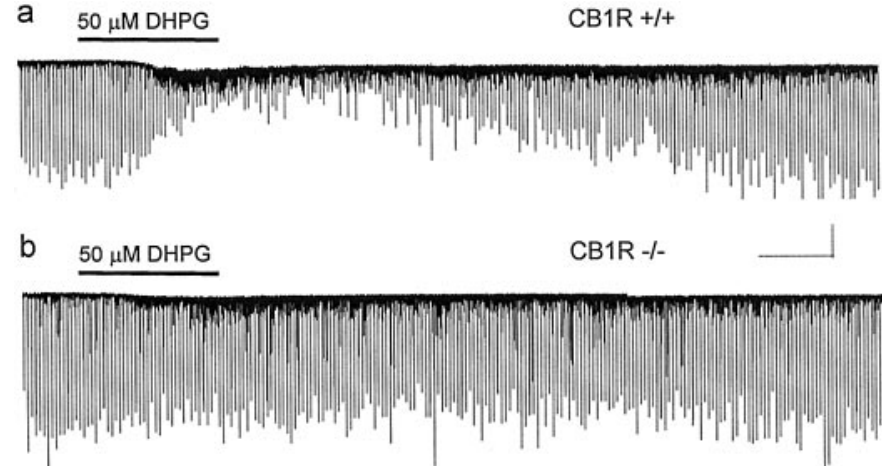

c

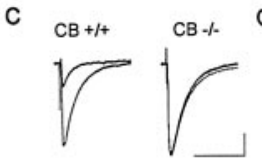

d $\mathrm{CB}+/+$

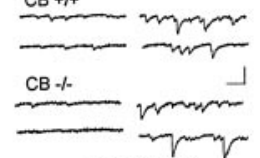

e

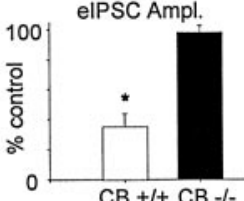

$\mathrm{CB}+1+\mathrm{CB}-1-$
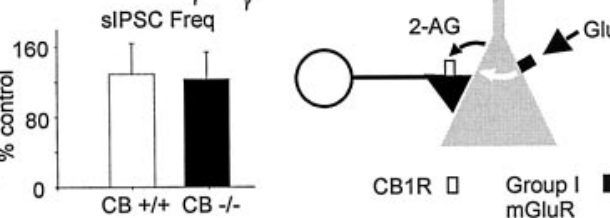

CB1R P Group I

Figure 3. The group I mGluR agonist DHPG does not suppress eIPSCs in $\mathrm{CB} 1 \mathrm{R}^{-1-}$, yet enhances sIPSCs in both types of mice. $a$, DHPG decreased eIPSCs and increased sIPSC frequency. $b$, A $50 \mu \mathrm{M}$ concentration of DHPG did not decrease eIPSCs, but enhanced sIPSC activity in a cell from a CB1R ${ }^{-1-}$ mouse. Calibration: $a, b, 200 \mathrm{pA}, 60 \mathrm{sec} . c$, Means of eIPSCs in control solution and during DHPG application illustrate the difference between $\mathrm{CB} 1 \mathrm{R}^{-/-}$and $\mathrm{CB} 1 \mathrm{R}^{+/+}$mice in the degree of eIPSC suppression by DHPG. Calibration: $100 \mathrm{pA}, 50 \mathrm{msec}$. Histogram shows eIPSC suppression as a percentage of control eIPSC amplitude caused by DHPG (suppression in CB1 ${ }^{+1+}, 35.5 \pm 8.4 \%, n=$ 4; suppression in $\left.\mathrm{CB} 1 \mathrm{R}^{-/-}, 98.0 \pm 5.5 \% ; n=6 ; p<0.001\right)$. $d$, Sample traces show increases in sIPSC frequency (measured as number of events over a $10 \mathrm{sec}$ period) caused by DHPG in both CB1 $\mathrm{R}^{+/+}$and $\mathrm{CB} 1 \mathrm{R}^{-1-}$

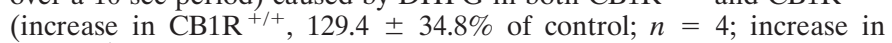
$\mathrm{CB} 1 \mathrm{R}^{-/-}, 123.4 \pm 30.9 \%$ increase of control; $n=5$; difference not significant; $p=0.90)$. Calibration: $50 \mathrm{pA}, 100 \mathrm{msec}$. $e$, Hypothetical model: glutamate activates group I mGluRs on pyramidal cells and causes release of the endocannabinoid 2-AG. 2-AG activates presynaptic CB1Rs on interneurons and decreases GABA release.

the $\mathrm{CB} 1 \mathrm{R}^{-1-}$. These results support the endocannabinoid hypothesis of DSI and confirm that $\mathrm{CB} 1 \mathrm{R}^{-/-}$mice are an effective tool for investigating the interactions between DSI and mGluRs.

If the interactions between $\mathrm{CB} 1 \mathrm{R}$ and mGluR occurred through cross-over at the G-protein level, then the mGluR agonists would continue to suppress eIPSCs in CB1 $\mathrm{R}^{-/-}$mice. Surprisingly, we found that even high concentrations of mGluR agonists had no effect on eIPSCs: as shown in Figure 3c, ACPD, or DHPG, at $50 \mu \mathrm{M}$, decreased eIPSCs by $\sim 65 \%(n=4)$ in $\mathrm{CB} 1 \mathrm{R}^{+/+}$mice, but in CB1R ${ }^{-/-}$mice, they reduced eIPSCs by only $\sim 2 \%(n=6)$. Although incapable of reducing eIPSCs in the CB1 ${ }^{-1-}$ mice, ACPD and DHPG markedly enhanced sIPSC frequency in both CB1 $\mathrm{R}^{+/+}$and CB1 $\mathrm{R}^{-/-}$mice (Fig. $3 d$ ), as in rats (Miles and Poncer, 1993) (Fig. 2a). Thus, the lack of effect of mGluR agonists on eIPSCs did not reflect a defect in the expression or function of group I mGluRs in $\mathrm{CB}_{1} \mathrm{R}^{-/-}$mice. We conclude that the cross-over hypothesis cannot account for our data, and that therefore the CB1R is the final common pathway for the enhancement of DSI by mGluRs and for eIPSC suppression by mGluR agonists.

\section{DISCUSSION}

The data show that activation of metabotropic glutamate receptors can drive the endocannabinoid system in the hippocampus. All suppressive effects of group I mGluRs on IPSCs in CA1, including enhancement of DSI, are actually mediated by endocannabinoids. Tight coupling between mGluRs and the endocannabinoid system accounts for the close mimicry between properties of mGluR-mediated suppression of IPSCs and DSI in hippocampus (Morishita et al., 1998; Morishita and Alger, 1999). Activation of group I mGluRs can modulate DSI, but is not required for DSI induction. Variable suppression of DSI by mGluR antagonists could reflect variable contributions of mGluR activation to DSI because of different ambient glutamate levels. Release of glutamate from synapses, glial cells (Araque et al., 2000), and neuronal somata (Attwell et al., 1993) can contribute to changes in ambient glutamate concentrations. This can help explain reported failures of MCPG to block DSI, because neither stratum pyramidale-evoked eIPSCs in the slice preparation (Wilson and Nicoll, 2001) nor unitary IPSCs in dissociated tissue culture (Ohno-Shosaku et al., 2001) should be associated with increased levels of glutamate. Indeed, synaptic release of glutamate may prove to be a new means of inducing DSI. We previously reported (Morishita and Alger, 2001) that DSI can be induced by direct dendritic depolarization in recordings $\sim 350$ $\mu \mathrm{m}$ from the cell soma. Interneuronal axons possessing CB1 receptors are distributed throughout the dendritic region (Hajos et al., 2000), so it is possible that mGluR-induced endocannabinoid release in the dendritic region induces local DSI. We speculate that mGluR activation enhances DSI by increasing the synthesis and release of endocannabinoids (Fig. 3e). Release of the endocannabinoid 2-arachidonyl glycerol (2-AG) is dramatically increased by stimulation of glutamatergic fibers in the hippocampus (Stella et al., 1997), and dopamine increases anandamide release in the striatum (Giuffrida et al., 1999). Synaptically released glutamate induces endocannabinoid-mediated depolarization-induced suppression of excitation through activation of postsynaptic group I mGluRs in the cerebellum (Maejima et al., 2001). Our data have important implications for understanding the often complex effects attributed to mGluR activation (Kullmann and Asztely, 1998). For example, some evidence interpreted in favor of glutamate "spillover" might actually be the result of glutamate-induced release of endocannabinoids. The physiological stimulation of mGluR5 may be required for cannabinoid-induced analgesia in the periaqueductal gray area (Palazzo et al., 2001), suggesting that our results have broad behavioral implications. It will be very interesting to learn whether metabotropic glutamate receptors are involved in any of the newly discovered roles of the endocannabinoid systems (Calignano et al., 2000; Hajos et al., 2000; Di Marzo et al., 2001; Kreitzer and Regehr, 2001).

\section{REFERENCES}

Ameri A (1999) The effects of cannabinoids on the brain. Prog Neurobiol 58:315-348.

Alger BE, Pitler TA, Wagner JJ, Martin LA, Morishita W, Kirov SA, Lenz RA (1996) Retrograde signalling in depolarization-induced suppression of inhibition in rat hippocampal CA1 cells. J Physiol (Lond) 496:197-209.

Araque A, Li N, Doyle RT, Haydon PG (2000) SNARE proteindependent glutamate release from astrocytes. J Neurosci 20:666-673.

Attwell D, Barbour B, Szatkowski M (1993) Nonvesicular release of neurotransmitter. Neuron 11:401-407.

Bouaboula M, Perrachon S, Milligan L, Canat X, Rinaldi-Carmona M, Portier M, Barth F, Calandra B, Pecceu F, Lupker J, Maffrand J-P, Le Fur G, Casellas P' (1997) A selective inverse agonist for central can- 
nabinoid receptor inhibits mitogen-activated protein kinase activation stimulated by insulin or insulin-like growth factor 1 . Evidence for a new model of receptor/ligand interactions. J Biol Chem 272:22330-22339.

Calignano A, La Rana G, Giuffrida A, Piomelli D (1998) Control of pain initiation by endogenous cannabinoids. Nature 394:277-281.

Calignano A, Katona I, Desarnaud F, Giuffrida A, La Rana G, Mackie K, Freund TF, Piomelli D (2000) Bidirectional control of airway responsiveness by endogenous cannabinoids. Nature 408:96-101.

Di Marzo V, Melck D, Bisogno T, De Petrocellis L (1998) Endocannabinoids: endogenous cannabinoid receptor ligands with neuromodulatory action. Trends Neurosci 21:521-528.

Di Marzo V, Goparaju SK, Wang L, Liu J, Batkai S, Jarai Z, Fezza F, Miura GI, Palmiter RD, Sugiura T, Kunos G (2001) Leptin-regulated endocannabinoids are involved in maintaining food intake. Nature 410:822-825.

Fitzjohn SM, Bortolotto ZA, Palmer MJ, Doherty AJ, Ornstein PL, Schoepp DD, Kingston AE, Lodge D, Collingridge GL (1998) The potent $\mathrm{mGlu}$ receptor antagonist LY341495 identifies roles for both cloned and novel mGlu receptors in hippocampal synaptic plasticity. Neuropharmacology 37:1445-1458.

Gereau IV RW, Conn PJ (1995) Multiple presynaptic metabotropic glutamate receptors modulate excitatory and inhibitory synaptic transmission in hippocampal area CA1. J Neurosci 15:6879-6889.

Giuffrida A, Parsons LH, Kerr TM,. Rodriguez de Fonseca F, Navarro M, Piomelli D (1999) Dopamine activation of endogenous cannabinoid signaling in dorsal striatum. Nat Neurosci 2:358-363.

Glitsch M, Llano I, Marty A (1996) Glutamate as a candidate retrograde messenger at interneurone-Purkinje cell synapses of rat cerebellum. J Physiol (Lond) 497:531-537.

Hajos N, Katona I, Naiem SS, Mackie K, Ledent C, Mody I, Freund TF (2000) Cannabinoids inhibit hippocampal GABAergic transmission and network oscillations. Eur J Neurosci 12:3239-3249.

Hoffman AF, Lupica CR (2000) Mechanisms of cannabinoid inhibition of $\mathrm{GABA}_{\mathrm{A}}$ synaptic transmission in the hippocampus. J Neurosci 20:2470-2479.

Katona I, Sperlagh B, Sik A, Kafalvi A, Vizi ES, Mackie K, Freund TF (1999) Presynaptically located CB1 cannabinoid receptors regulate GABA release from axon terminals of specific hippocampal interneurons. J Neurosci 19:4544-4558.

Kreitzer AC, Regehr WG (2001) Retrograde inhibition of presynaptic calcium influx by endogenous cannabinoids at excitatory synapses onto Purkinje cells. Neuron 29:717-727.

Kullmann DM, Asztely F (1998) Extrasynaptic glutamate spillover in the hippocampus: evidence and implications. Trends Neurosci 21:8-14.

Ledent C, Valverde O, Cossu G, Petitet F, Aubert J-F, Beslot F, Bohme GA, Imperato A, Pedrazzini T, Roques BP, Vassart G, Fratta W, Parmentier M (1999) Unresponsiveness to cannabinoids and reduced addictive effects of opiates in $\mathrm{CB} 1$ receptor knockout mice. Science 283:401-404.

Lenz RA, Alger BE (1999) Calcium dependence of depolarizationinduced suppression of inhibition in rat hippocampal CA1 pyramidal neurons. J Physiol (Lond) 521:147-157.

Levenes C, Daniel H, Soubrie P, Crepel F (1998) Cannabinoids decrease excitatory synaptic transmission and impair long-term depression in rat cerebellar Purkinje cells. J Physiol (Lond) 510:867-879.

Littman L, Robinson MB (1994) The effects of L-glutamate and trans-

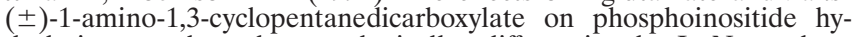
drolysis can be pharmacologically differentiated. J Neurochem 63:1291-1302.

Llano I, Leresche N, Marty A (1991) Calcium entry increases the sensitivity of cerebellar Purkinje cells to applied GABA and decreases inhibitory synaptic currents. Neuron 6:565-574.

Maejima T, Hasimoto K, Yoshida T, Aiba A, Kano M (2001) Presyn- aptic inhibition caused by retrograde signal from metabotropic glutamate to cannabinoid receptors. Neuron 31:463-475.

Martin LA, Wei D-S, Alger BE (2001) Heterogeneous susceptibility of $\mathrm{GABA}_{\mathrm{A}}$ receptor-mediated IPSCs to depolarization-induced suppression of inhibition in rat hippocampus. J Physiol (Lond) 532:685-700.

Matsuda LA, Lolait SJ, Brownstein MJ, Young AC, Bonner TI (1990) Structure of a cannabinoid receptor and functional expression of the cloned cDNA. Nature 346:561-564.

Miles R, Poncer J-C (1993) Metabotropic glutamate receptors mediate a post-tetanic excitation of guinea-pig hippocampal inhibitory neurones. J Physiol (Lond) 463:461-473.

Morishita W, Alger BE (1997) $\mathrm{Sr}^{2+}$ supports depolarization-induced suppression of inhibition and provides new evidence for a presynaptic expression mechanism in rat hippocampal slices. J Physiol (Lond) 505:307-317.

Morishita W, Alger BE (1999) Evidence for endogenous excitatory amino acids as mediators in DSI of $\mathrm{GABA}_{\mathrm{A}}$ ergic transmission in hippocampal CA1. J Neurophysiol 82:2556-2564.

Morishita W, Alger BE (2001) Direct depolarization and antidromic action potentials transiently suppress dendritic IPSPs in hippocampal CA1 pyramidal cells. J Neurophysiol 85:480-484.

Morishita W, Kirov SA, Alger BE (1998) Evidence for metabotropic glutamate receptor activation in the induction of depolarizationinduced suppression of inhibition in hippocampal CA1. J Neurosci 18:4870-4882.

Ohno-Shosaku T, Maejima T, Kano M (2001) Endogenous cannabinoids mediate retrograde signals from depolarized postsynaptic neurons to presynaptic terminals. Neuron 29:729-738.

Palazzo E, Marabese I, de Novellis V, Oliva P, Rossi F, Berrino L, Maione S (2001) Metabotropic and NMDA glutamate receptors participate in the cannabinoid-induced antinociception. Neuropharmacology 40:319-326.

Pertwee RG (1997) Pharmacology of cannabinoid CB1 and CB2 receptors. Pharmacol Ther 74:129-180.

Pin J-P, Duvoisin R (1995) Neurotransmitter receptors I. The metabotropic glutamate receptors: structure and functions. Neuropharmacology $34: 1-26$.

Pitler TA, Alger BE (1992) Postsynaptic spike firing reduces synaptic GABAA responses in hippocampal pyramidal cells. J Neurosci 12:4122-4132.

Stella N, Schweitzer P, Piomelli D (1997) A second endogenous cannabinoid that modulates long-term potentiation. Nature 388:773-778.

Takahashi KA, Linden DJ (2000) Cannabinoid receptor modulation of synapses received by cerebellar Purkinje cells. J Neurophysiol 83:1167-1180.

Tsou K, Mackie K, Sanudo-Pena MC, Walker JM (1999) Cannabinoid CB1 receptors are localized primarily on cholecystokinin-containing GABAergic interneurons in the rat hippocampal formation. Neuroscience 93:969-975.

Vasquez C, Lewis DL (1999) The CB1 cannabinoid receptor can sequester G-proteins, making them unavailable to couple to other receptors. J Neurosci 19:9271-9280.

Vincent P, Armstrong CM, Marty A (1992) Inhibitory synaptic currents in rat cerebellar Purkinje cells: modulation by postsynaptic depolarization. J Physiol (Lond) 456:453-471.

Wilson RI, Nicoll RA (2001) Endogenous cannabinoids mediate retrograde signalling at hippocampal synapses. Nature 410:588-592.

Wilson RI, Kunos G, Nicoll RA (2001) Presynaptic specificity of endocannabinoid signaling in the hippocampus. Neuron 31:1-20.

Zilberter Y (2000) Dendritic release of glutamate suppresses synaptic inhibition of pyramidal neurons in rat neocortex. J Physiol (Lond) 528:489-496. 